\title{
Avian malaria, ecological host traits and mosquito abundance in southeastern Amazonia
}

\author{
ALAN FECCHIO ${ }^{1}$, VINCENZO A. ELLIS ${ }^{2}$, JEFFREY A. BELL ${ }^{3}$, \\ CHRISTIAN B. ANDRETTI ${ }^{4}$, FERNANDO M. D'HORTA ${ }^{5}$, ALLAN M. SILVA ${ }^{6}$, \\ VASYL V. TKACH ${ }^{3}$ and JASON D. WECKSTEIN ${ }^{7}$ \\ ${ }^{1}$ Department of Ornithology, Academy of Natural Sciences of Drexel University, Philadelphia, PA 19103, USA \\ ${ }^{2}$ Departamento de Biologia Geral, Universidade Federal de Minas Gerais, Belo Horizonte, MG 31270-901, Brazil \\ ${ }^{3}$ Department of Biology, University of North Dakota, Grand Forks, ND 58201, USA \\ ${ }^{4}$ Curso de Pós-graduação em Zoologia, Pontifícia Universidade Católica do Rio Grande do Sul, Porto Alegre, RS, Brazil \\ ${ }^{5}$ Instituto Nacional de Pesquisas da Amazônia, Manaus, AM 69060-001, Brazil \\ ${ }^{6}$ Seção de Entomologia, Laboratório Central, Secretaria de Estado da Saúde do Paraná, São José dos Pinhais, PR 83060- \\ 500, Brazil \\ ${ }^{7}$ Department of Ornithology, Academy of Natural Sciences and Department of Biodiversity, Earth, and Environmental \\ Science, Drexel University, Philadelphia, PA 19103, USA
}

(Received 7 November 2016; revised 16 February 2017; accepted 17 February 2017; first published online 27 March 2017)

\begin{abstract}
SUMMARY
Avian malaria is a vector transmitted disease caused by Plasmodium and recent studies suggest that variation in its prevalence across avian hosts is correlated with a variety of ecological traits. Here we examine the relationship between prevalence and diversity of Plasmodium lineages in southeastern Amazonia and: (1) host ecological traits (nest location, nest type, flocking behaviour and diet); (2) density and diversity of avian hosts; (3) abundance and diversity of mosquitoes; and (4) season. We used molecular methods to detect Plasmodium in blood samples from 675 individual birds of 120 species. Based on cytochrome $b$ sequences, we recovered 89 lineages of Plasmodium from 136 infected individuals sampled across seven localities. Plasmodium prevalence was homogeneous over time (dry season and flooding season) and space, but heterogeneous among 51 avian host species. Variation in prevalence among bird species was not explained by avian ecological traits, density of avian hosts, or mosquito abundance. However, Plasmodium lineage diversity was positively correlated with mosquito abundance. Interestingly, our results suggest that avian host traits are less important determinants of Plasmodium prevalence and diversity in southeastern Amazonia than in other regions in which they have been investigated.
\end{abstract}

Key words: Culicidae, Haemosporidian parasites, mosquito diversity, parasite diversity, Plasmodium, vectors.

\section{INTRODUCTION}

Many factors have been proposed to explain parasite diversity (Poulin, 1997). For example, previous studies have shown that species richness increases towards the equator for some groups of parasitic organisms (Rohde and Heap, 1998; Guernier et al. 2004; Nunn et al. 2005). However, a recent meta-analysis of 62 studies involving animal, plant and fungal hosts showed that there was no strong evidence for an effect of latitude on parasite species richness (Kamiya et al. 2014). Parasite diversity might be determined by characteristics of hosts rather than those of the environment. For example, host body size, population density and geographic range have all been suggested as universal predictors of variation in parasite species richness (Kamiya et al. 2014). Nevertheless, the meta-analysis of Kamiya et al. (2014) did not include vector-transmitted parasites. Host density

* Corresponding author: Laboratório de Evolução e Biogeografia, Universidade Federal da Bahia, Rua Barão de Jeremoabo, 147, Salvador, BA 40170115, Brazil. E-mail: alanfecchio@gmail.com can be especially important for parasites, which depend on hematophagous insects for reproduction because the concentration of hosts in a given area potentially affects the prevalence and transmission of vector-borne pathogens by influencing encounter rates between vectors and susceptible hosts (Nunn and Heymann, 2005).

Avian malaria is a worldwide, vector-transmitted disease caused by haemosporidian parasites in the genus Plasmodium (Valkiūnas, 2005). These parasites reproduce sexually in female mosquito vectors from the genera Culex, Aedes, Culiseta, Anopheles, Mansonia, Aedeomyia and Coquillettidia (Diptera: Culicidae) (Valkiūnas, 2005; Njabo et al. 2009; Santiago-Alarcon et al. 2012). Environmental factors, especially temperature, can play a role in the distribution, prevalence and transmission of these parasites (Gonzalez-Quevedo et al. 2014; Oakgrove et al. 2014). Temperature constrains not only parasite sporogonic development (LaPointe et al. 2010), but also influences the activity and development of the mosquito vectors, which are important determinants of the prevalence and transmission of avian malaria. 
However, temperature, among other environmental variables, did not explain avian malaria prevalence in avian species across several sites in South Africa (Okanga et al. 2013). As Okanga et al. (2013) pointed out, this suggests that the prevalence of avian malaria parasites may also be determined by factors related to their avian hosts and mosquito vectors (see also Ellis et al. 2015).

Several studies have investigated the effect of avian ecological traits on the probability of infection by Plasmodium and other related haemosporidians (Ricklefs et al. 2005; Fecchio et al. 2011, 2013; Svensson-Coelho et al. 2013; González et al. 2014; Lutz et al. 2015; Matthews et al. 2016). In these studies, variation in haemosporidian prevalence is thought to be a result of the host's capability to resist and control infection or the result of differential exposure to parasites. However, most studies have not considered the role of vectors in explaining these patterns (but see Medeiros et al. 2015).

At a finer spatial scale, infection risk for Plasmodium in blue tit populations increased with increasing proximity to a large water source, possibly as result of increased vector abundance (Wood et al. 2007). Haemosporidian prevalence was also higher in the wettest of two western Amazonian 100 ha forest plots that were otherwise similar with respect to forest type, altitude, human disturbance and flooding (Svensson-Coelho et al. 2013). These studies corroborate the idea that prevalence of blood parasites is higher at sites where vectors are more abundant.

Besides vector abundance, avian host density could also play a role in determining the prevalence of avian malaria parasites. For example, host population density can influence the spread and distribution of parasites by increasing the probability that the vectors and thus the parasites can come into contact with hosts (Anderson and May, 1978; Ellis et al. 2017). Furthermore, Drovetski et al. (2014) found that haemosporidian lineages infected abundant bird species more frequently than less common host species in four avian communities in Africa, Asia and Europe.

To improve our understanding of avian malaria transmission, we sought to determine which biological factors (mosquito abundance and diversity; host ecological traits and density) explain the prevalence and diversity of Plasmodium lineages across seven locations along the Tapajós and Jamanxim rivers in Brazilian Amazonia. Specifically, we predicted that: (1) Plasmodium prevalence in a given host species would be positively correlated with the host species' density; (2) Plasmodium lineage diversity would be positively correlated with avian host diversity; (3) avian ecological traits would explain some of the variation in Plasmodium prevalence; and (4) the prevalence and diversity of avian Plasmodium lineages would be positively correlated with the abundance and diversity of mosquitoes. A secondary motivation of our study was to provide information on the diversity and distribution of ornithophilic mosquitoes in a region of Amazonia that has not previously been explored with respect to these insects.

MATERIALS AND METHODS

\section{Sampling sites}

The study area was located midway down the Tapajós River, a major south bank tributary of the Amazon River. Sampling was carried out along both banks of the Tapajós River covering both the Rondônia and Tapajós areas of endemism (Silva et al. 2005). We also sampled the right bank of its most important tributary, the Jamanxim River (Fig. 1). The area comprises a wide variety of microhabitats, with the terra firme and igapó forests being the most broadly distributed. Sampling was conducted along six transects of five $\mathrm{km}$ in length, beginning in the seasonally flooded forest (igapó) and crossing the interior of terra firme forest. We also sampled a $250 \mathrm{~m}$ transect on a river island. We named these seven sites as follows: the first letter of the label is the first letter of the river name (' $\mathrm{T}$ ' for Tapajós and ' $\mathrm{J}$ ' for Jamanxim); the second letter is the margin of the river (' $L$ ' for left bank, ' $R$ ' for right bank and ' $\mathrm{I}$ ' for the island); site names also include a number to identify unique sampling sites on the same bank of the same river.

\section{Bird sampling}

We placed five mist net lines within each transect. These five mist net lines were each separated by 1 $\mathrm{km}$ and contained ten nets. The 50 mist nets $(12 \mathrm{~m}$ length $\times 3 \mathrm{~m}$ height) remained open for three consecutive mornings at each of the seven transect sites. Owing to the small size of the river island, the mist nets were arranged in a single $250 \mathrm{~m}$ line and were sampled with the same effort as the others sites. Blood sampling of captured birds took place during two distinct seasons, the dry season for the sites TL1, TL2, TL4, TR1 and JR1 (18 July-3 August 2012) and flooding period for the sites TL1, TL2, TL3 and TI (1-17 October 2012), thus only two sites, TL1 and TL2, were sampled during both the dry and flooding seasons. At each site, to allow sufficient time for transmission of Plasmodium to avian hosts, avian blood samples were collected from individual birds shortly after ( 2-3 weeks) mosquito vectors were also sampled. Netted birds were bled by brachial venipuncture using heparinized capillary tubes. Blood samples were stored in 95\% ethanol until DNA extraction. After blood collection, birds were ringed and released, or euthanized and prepared for museum specimens. All tissue samples and birds were 


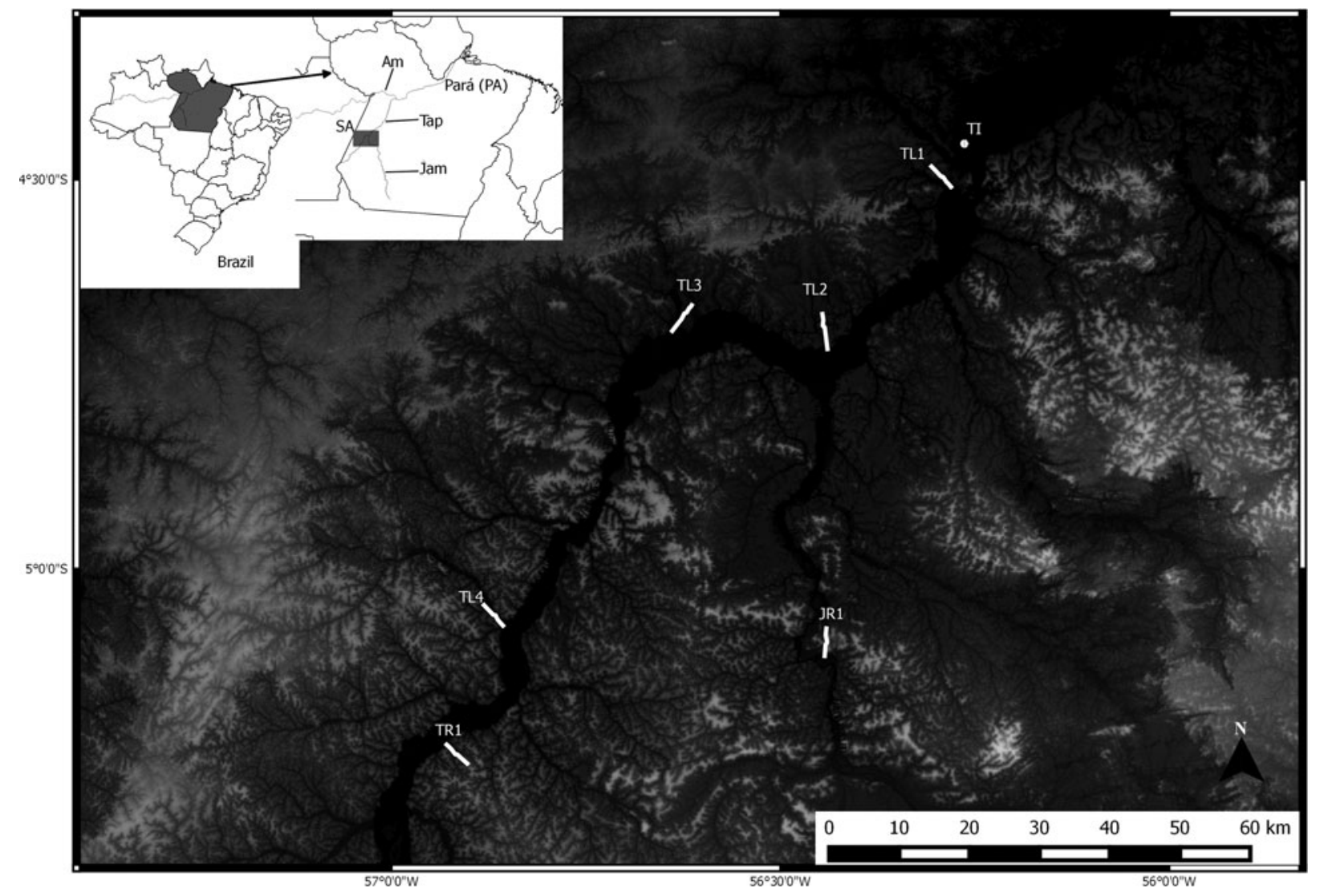

Fig. 1. Map showing the seven sampling sites along the Tapajós and Jamanxim rivers. Background shading corresponds to elevation with lower areas represented by darker shading. The inset shows the state of Pará, Brazil, and the study area (SA) is represented as a dark grey rectangle within the state. Am, Amazon River; Jam, Jamanxim River; and Tap, Tapajós River.

collected or ringed under appropriate permits from Brazil (IBAMA no 22/2012 and ICMBio no 004/ 2012). Tissue samples and voucher specimens were deposited in the Bird Collection at the Instituto Nacional de Pesquisas da Amazônia - INPA, Manaus, Brazil. Species nomenclature follows Piacentini et al. (2015).

Besides mist net sampling, we conducted point count surveys (10 min each), spread along transects at every $500 \mathrm{~m}$, totalling 11 points per transect. Each point was sampled for four consecutive days at each sampling period. We estimated density of individual species in each area using MCDS (Multiple Covariates Distance Sampling) as implemented in the program Distance 6.0 (Thomas et al. 2009). The analyses were stratified to obtain density estimates for each area. We truncated $10 \%$ of data with larger distances within each species to avoid double counting the same individual, as recommended by Buckland et al. (2001). For each species, we compared the following models: (1) half normal and hazard rate set as functions of expansion adjusted by cosine; (2) simple polynomial; and (3) polynomial hermite. We then calculated the Akaike's Information Criterion (AIC) for each model and chose the one with the lowest AIC score.

\section{Mosquito sampling}

Mosquitoes were collected using light traps powered by $12 \mathrm{~V}$ batteries as designed by Falcão (1981). The traps were installed in the same sampling transects used for mist netting birds, and were distributed in two vertical layers, at ground level (suspended approximately $1 \mathrm{~m}$ above the ground) and in the forest canopy (suspended between 10 and $15 \mathrm{~m}$ above the ground). A total of 14 traps were installed simultaneously in each transect and these were located at equidistant points starting at the river bank and ending at $4 \mathrm{~km}$ from the river bank in the interior of terra firme forest. Mosquito collections were made during three consecutive nights, between 18:00 and 21:00 $\mathrm{h}$ during both the dry season for the sites TL1, TL2, TL4, TR1 and JR1 (2-13 July 2012) and the flooding season for the sites TL1, TL2, TL3 and TI (12-23 September 2012), thus only two sites, TL1 and TL2, were sampled during both the dry and flooding seasons. Mosquitoes were stored in small plastic vials labelled with the corresponding data for each sample. In the laboratory, the female mosquitoes were separated and identified taxonomically using external morphological characters observed using a stereoscope. We 
only used female mosquitoes for abundance estimation because only females are potential vectors for Plasmodium. For species determination, we used keys published by Galindo et al. (1954) and Forattini (1962, 1965a, $b$, 2002). We used the infrageneric classification scheme of the genus Anopheles from McKeon et al. (2013), Moreno et al. (2013) and RuizLopez et al. (2013), which differentiates among groupings of cryptic but presently unnamed lineages. The abbreviation of genera and subgenera follows the guidelines suggested by Reinert (2001), according to the newly proposed mosquito nomenclature of the Walter Reed Biosystematics Unit, Smithsonian Institution (catalogue available at http://www.mosqui tocatalog.org/taxon_table.aspx) and Harbach (2013) in the Mosquito Taxonomic Inventory (www.mos quito-taxonomic-inventory.info/).

\section{Parasite detection}

DNA was extracted from avian blood samples using the Qiagen DNeasy 96 Blood and Tissue kit (Qiagen, Valencia, CA), following the Qiagen protocol for blood in 95\% ethanol. Total DNA was screened by real-time PCR to detect haemosporidian DNA following the protocol of Bell et al. (2015). Positive and negative controls were included in all real-time PCR runs. Samples identified as positive by real-time PCR underwent subsequent nested PCR, as outlined in Bell et al. (2015), to amplify a 477 bp fragment of the cytochrome $b$ gene.

Positive nested PCR products were purified using ExoSAP-IT (Affymetrix, Santa Clara, CA), sequenced using BigDye terminator v3.1 cycle sequencing kit (Applied Bio systems, Foster City, CA), and run on an ABI 3100 DNA sequencer (Applied Bio systems, Foster City, CA). For sequencing protocol and primers see Bell et al. (2015). Forward and reverse sequences were visualized and assembled using Sequencher v.5.0.1 (Gene Codes Corp., Ann Arbor, MI). Chromatograms that showed the presence of multiple infections were scored as co-infections. Coinfections were separated using the program PHASE 2.1.1 (Stephens et al. 2001; Stephens and Donnelly, 2003) following the protocol of Harrigan et al. (2014). Assembled sequences were aligned using BioEdit v7.2.0 (Hall, 1999) and collapsed to unique haplotypes using the FaBox haplotype collapser and converter tool (Villesen, 2007). Sequence identities were verified with a local BLAST against the MalAvi database (Bensch et al. 2009) using BioEdit v7.2.0 (Hall, 1999). New lineages were named after the host of origin following standard protocol (Bensch et al. 2009), using a sixletter code produced by using the first three letters of both the host genus and specific epithet followed by a number to denote multiple lineages from a single host species. For example, lineage WILPOE01 represents the first lineage obtained from Willisornis poecilinotus. All sequences were deposited in GenBank
(Accession No KU562250-KU562512) and the MalAvi database.

Assembled sequences of unique lineages were used to reconstruct a molecular phylogeny using Bayesian inference (BI) as implemented in MrBayes v. 3.2.2 (Huelsenbeck and Ronquist, 2001; Ronquist and Huelsenbeck, 2003) and the GTR + I + G model of nucleotide substitution as determined by jModelTest (Darriba et al. 2012); Leucocytozoon fringillarum (FJ168564) served as the outgroup. The BI analysis was run until the S.D. of split frequencies stabilized below $0 \cdot 01$. Twenty-five percent of resulting trees were discarded as burn in. The resulting consensus tree was visualized in FigTree (Rambaut, 2009).

\section{Statistical analyses and modelling}

We were interested in testing whether the prevalence of Plasmodium parasites was related to the density of avian hosts within the different sites sampled. To do this we first restricted our analysis to species sampled at least five times within a site; this left us with three sites (TL1, TL2 and TL3) each including more than three species that met our sample size criterion (Table A2). We then calculated prevalence for each species at each site separately as the number of Plasmodium-infected individuals divided by the total number of individuals sampled of a particular species at a particular site. Individuals infected with only Haemoproteus parasites were considered uninfected for this analysis since we did not sample the arthropod vectors for this parasite genus and because birds can be found with mixed infections of both genera (Valkiūnas, 2005). Individual birds infected with both Plasmodium and Haemoproteus were considered infected. We then ran three generalized linear models, one for each site, with prevalence as the response variable and host density as the explanatory variable with a quasibinomial error structure to account for overdispersion (Bolker et al. 2009). We entered two vectors of infected and uninfected individuals into the model to weight prevalence by sample size as is standard when running such models in R; see Crawley, 2012). Since sampling took place in two seasons for sites TL1 and TL2, we compared prevalence of Plasmodium parasites between seasons (within sites; prevalence was calculated for all individuals, i.e. not separated by host species, sampled within each season for each of the two sites) using chi-squared tests to confirm that seasons could be grouped for this analysis.

We tested the hypothesis that Plasmodium lineage diversity was related to the diversity of avian hosts across all seven sampling sites. For this we calculated a Simpson's index of diversity for all avian hosts that were sampled (117 species) and one for all parasite lineages within each sampling site using the 'diversity' function in the R package vegan (Oksanen et al. 2015). We then used Spearman's rank correlation tests 
(correlation statistic is $\rho$ ) to determine whether the variables were correlated across sampling sites.

We were also interested in testing whether the prevalence of Plasmodium parasites across avian host species was related to the following host ecological variables: nest location (ground, understory, sub canopy, canopy and cliff/bank), nest type (open cup, closed cup and cavity), flocking behaviour (solitary/family, single species and mixed species), and diet (insectivore, frugivore/granivore and omnivore). We scored these traits for all species sampled using a combination of The Birds of South America Volumes I and II (Ridgely and Tudor, 1989a, b), Neotropical Birds: Ecology and Conservation (Stotz et al. 1996), The Cornell Lab of Ornithology: Neotropical Birds (http://www.neotrop ical.birds.cornell.edu/portal/home) and WikiAves (http://www.wikiaves.com.br). We pooled our site data for this analysis because: (1) we did not expect site to influence the relationship of prevalence and ecological host traits (e.g. Matthews et al. 2016); and (2) because we did not find any significant differences in the prevalences of individual species sampled at multiple sites in our study (results not shown). We therefore constructed a generalized linear model with Plasmodium prevalence (weighted by sample size) as the response variable and each of the ecological variables as explanatory variables. We ran the model with a quasibinomial error structure to account for overdispersion and only included species with at least five individuals sampled ( $n=44$ avian species). Initially we included the taxonomic family of host species as an explanatory variable in the model to account for potential differences in prevalence among families, but sparse sampling led to uninterpretable estimates of family-level prevalences and so we dropped family from our final model. We also ran Wald chi-squared tests on each of the explanatory variables in the model using the function 'wald.test' in the R package aod (Lesnoff and Lancelot, 2012).

Finally, we tested the hypothesis that the prevalence and diversity of Plasmodium lineages were positively related to the abundance and diversity of mosquitoes across all seven of our sampling sites using Spearman's rank correlation tests. Here we calculated parasite prevalence for sites rather than for species by dividing the total number of infected individuals by the total number of individuals sampled in a site irrespective of host species. We again calculated a Simpson's index of diversity for Plasmodium lineages and one for mosquitoes within each sampling site.

All statistical analyses were performed in $\mathrm{R}$ version 3.2.3 (R Core Team, 2015).

\section{RESULTS}

\section{Prevalence and diversity of Plasmodium lineages}

We analysed 675 birds of 120 species sampled in seven communities along the Tapajós and Jamanxim rivers
Table 1. Prevalence of Plasmodium per site along the Tapajós and Jamanxin rivers, southeastern Amazonia, Brazil. Specific site location information can be found in Fig. 1

\begin{tabular}{llcl}
\hline \hline Location & $\begin{array}{c}\text { Sampled } \\
\text { individuals }\end{array}$ & Infected & Prevalence (\%) \\
\hline TL1 & 151 & 38 & $25 \cdot 2$ \\
TL2 & 137 & 17 & $12 \cdot 4$ \\
TL3 & 142 & 31 & $21 \cdot 8$ \\
TL4 & 60 & 10 & $16 \cdot 7$ \\
TR1 & 61 & 13 & $21 \cdot 3$ \\
TI & 85 & 15 & $17 \cdot 7$ \\
JR1 & 39 & 12 & $30 \cdot 8$ \\
& 675 & 136 & $20 \cdot 1$ \\
\hline \hline
\end{tabular}

(Fig. 1, Table A1). Plasmodium infections were detected in 136 individuals from 51 host species with a prevalence of $20 \%$ (Table A1). Infection prevalence varied among well sampled host species $(>10$ individuals screened), ranging from 0 to $64 \%$ ('Table A1). Plasmodium prevalence was homogeneous across sites, ranging from 12 to $31 \%\left(\chi^{2}=11 \cdot 282\right.$, D.F. $=6, P=0.080$; Table 1$)$. Based on cytochrome $b$ divergence, we recovered 89 haemosporidian lineages within the genus Plasmodium, of which 81 (91\%) were reported for the first time (Fig. 2). Although there are several well resolved and supported clades within the phylogeny, the general pattern is one of many polytomies with low node support (Fig. 2). When mapped onto the phylogeny, host family shows little perceivable pattern within the phylogeny, dominated by the highly sampled family Thamnophilidae. In several cases, individual Plasmodium lineages were recovered from more than one host family, with three Plasmodium lineages found in individual hosts from four different host families.

We sampled birds at sites TL1 and TL2 during the dry and flooding periods, allowing us to test for seasonal differences in prevalence. We found no differences in overall prevalence of Plasmodium parasites between the two seasons within each site (site TL1, $\chi^{2}=0$, D.F. $=1, P=1$; site TL2, $\chi^{2}=0 \cdot 703$, D.F. $=1, P=0 \cdot 402)$. For these tests we used ten host species from site TL1 and nine host species from the site TL2 for which we had sampled at least five individuals. We also found no differences in prevalence between seasons for individual host species (results not reported).

\section{Avian host ecology and Plasmodium prevalence}

Prevalence of Plasmodium (calculated for each host species within sites) was positively related to host density at site TL3 (GLM coefficient $=0 \cdot 186 \pm$ 0.05 s.E., $P=0 \cdot 037, n=5$ ), but not at sites TL1 (0.027 \pm 0.09 s.E., $P=0.769, \quad n=8)$ and TL2 $(-0 \cdot 096 \pm 0 \cdot 20$ s.E., $P=0 \cdot 661, n=6)$. However, the 


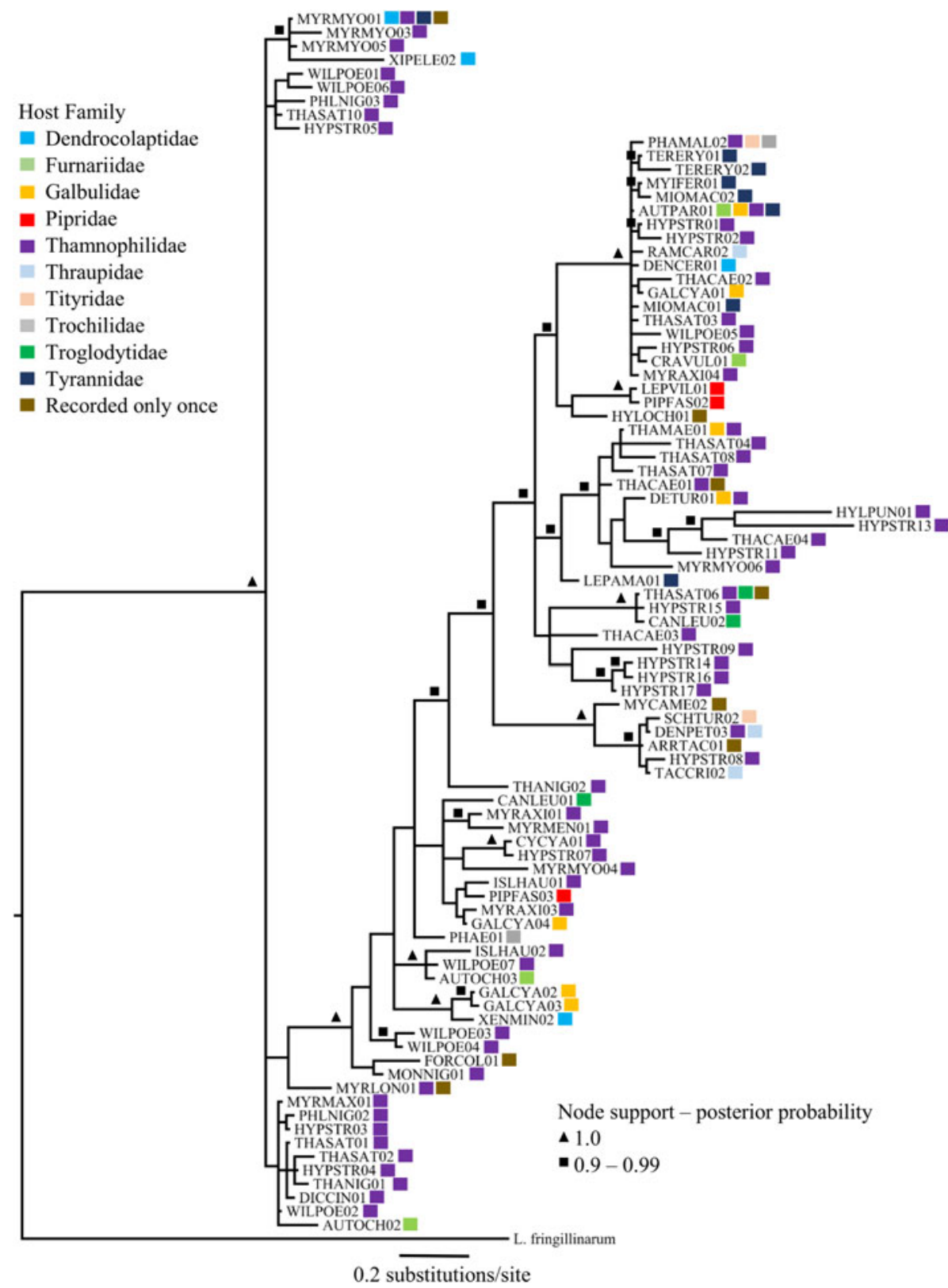

Fig. 2. BI phylogenetic reconstruction of Plasmodium lineages recovered from sites along the Tapajós and Jamanxim rivers. Posterior probability support above 0.9 is noted at the base of nodes and host family is noted next to terminal taxon labels.

relationship at site TL3 was based on only five host species, and would not be considered significant after a Bonferroni correction (after three tests, alpha $=0 \cdot 05 / 3$ or $0 \cdot 017$; Table A2). The diversity of Plasmodium parasites was not related to the diversity of avian hosts $(\rho=0 \cdot 49, P=0 \cdot 268, n=7)$.

We found no relationship between ecological traits of the hosts and the prevalence of Plasmodium parasites. We report coefficients and significance of each category of the explanatory ecological variables in Table 2 (results of each host trait modelled separately can be found in Table A3). We also ran Wald chi-squared tests for each ecological variable across all coefficients and none were significant (nest location: $\chi^{2}=1 \cdot 4$,
D.F. $=4, P=0 \cdot 85$; nest type: $\chi^{2}=4 \cdot 6$, D.F. $=2, P$ $=0 \cdot 10$; flocking behaviour: $\chi^{2}=1 \cdot 6$, D.F. $=2, P=$ $0 \cdot 45$; diet: $\chi^{2}=2 \cdot 1$, D.F. $\left.=2, P=0 \cdot 35\right)$. For this analysis, we used 504 birds of 44 species with a minimum of five individuals sampled per species. Plasmodium infections were detected in 101 individuals from 23 host species with a prevalence of $20 \%$ (Table A4).

\section{Mosquitos, prevalence and diversity of Plasmodium lineages}

We collected 511 female mosquitoes from 56 species and morpho-species belonging to 11 genera ('Tables A5 and A6). We ran paired Mann-Whitney $U$ tests 
Table 2. The results of a generalized linear model relating four avian ecological traits to the prevalence of Plasmodium parasites in avian hosts

\begin{tabular}{|c|c|c|c|c|}
\hline & $\begin{array}{c}\text { Estimate of } \\
\text { coefficient }\end{array}$ & S.E. & $t$ value & $P$ \\
\hline Intercept & $-0 \cdot 262$ & $0 \cdot 704$ & $-0 \cdot 372$ & $0 \cdot 712$ \\
\hline Understory & $-0 \cdot 022$ & $0 \cdot 801$ & $-0 \cdot 028$ & 0.978 \\
\hline Sub canopy & $-0 \cdot 622$ & $0 \cdot 891$ & $-0 \cdot 699$ & $0 \cdot 490$ \\
\hline Canopy & $0 \cdot 157$ & $1 \cdot 545$ & $0 \cdot 101$ & 0.920 \\
\hline Cliff or Bank & $0 \cdot 252$ & $1 \cdot 857$ & $0 \cdot 136$ & $0 \cdot 893$ \\
\hline Closed cup & $-1 \cdot 233$ & $1 \cdot 023$ & $-1 \cdot 206$ & $0 \cdot 237$ \\
\hline Cavity & $-1 \cdot 212$ & $0 \cdot 677$ & $-1 \cdot 790$ & $0 \cdot 083$ \\
\hline Single species & $-1 \cdot 800$ & $1 \cdot 509$ & $-1 \cdot 193$ & $0 \cdot 242$ \\
\hline $\begin{array}{l}\text { Mixed } \\
\text { species }\end{array}$ & $0 \cdot 123$ & $0 \cdot 559$ & $0 \cdot 220$ & $0 \cdot 827$ \\
\hline $\begin{array}{c}\text { Frugivore/ } \\
\text { Granivore }\end{array}$ & $-18 \cdot 759$ & $2562 \cdot 700$ & $-0 \cdot 007$ & $0 \cdot 9$ \\
\hline Omnivore & $-1 \cdot 536$ & $1 \cdot 061$ & $-1 \cdot 447$ & $0 \cdot 157$ \\
\hline
\end{tabular}

All of the explanatory ecological variables were categorical. We therefore report the estimate of the coefficient of each of the levels of those variables in relation to a base level. The base levels are as follows: nest location is ground, nest type is open cup, flocking is solitary/family, diet is insectivore. We report the estimate of the coefficient for each variable, its S.E., $t$ value and $P$ value; the null deviance of the model is 198.01 on 43 D.F. and the residual deviance is $128 \cdot 35$ on 33 D.F.

to compare mosquito abundance between seasons in sites TL1 and TL2. In site TL1, mosquito abundance was higher in the flooding period than in the dry season $(U=21 \cdot 5, P<0 \cdot 001)$, but in site TL2, there was no difference in mosquito abundance between seasons $(U=169, P=0 \cdot 441)$. In the other five sites, mosquito collection took place in only one season, preventing further seasonal comparisons (Tables A5 and A6).

The prevalence of Plasmodium parasites in avian hosts (calculated for an entire site and not by host species) was not related to the diversity $(\rho=-0 \cdot 46$, $P=0 \cdot 302)$ or the abundance $(\rho=-0 \cdot 22, P=0 \cdot 641)$ of mosquitoes across the seven sampling sites. The diversity of Plasmodium parasites was also not related to the diversity of mosquitoes $(\rho=0 \cdot 67$, $P=0 \cdot 102)$, but was positively related to the abundance of mosquitoes $(\rho=0.79, P=0.034)$ across sampling sites (Fig. 3). Since each of these tests represents a separate hypothesis, we did not apply a Bonferroni correction to the resulting $P$ values.

\section{DISCUSSION}

We investigated biotic factors that may determine the prevalence and diversity of Plasmodium parasites in Amazonian birds. We found that the diversity of Plasmodium lineages was positively correlated with mosquito abundance across the seven bird communities we sampled. Neither bird density nor bird diversity explained prevalence or lineage diversity

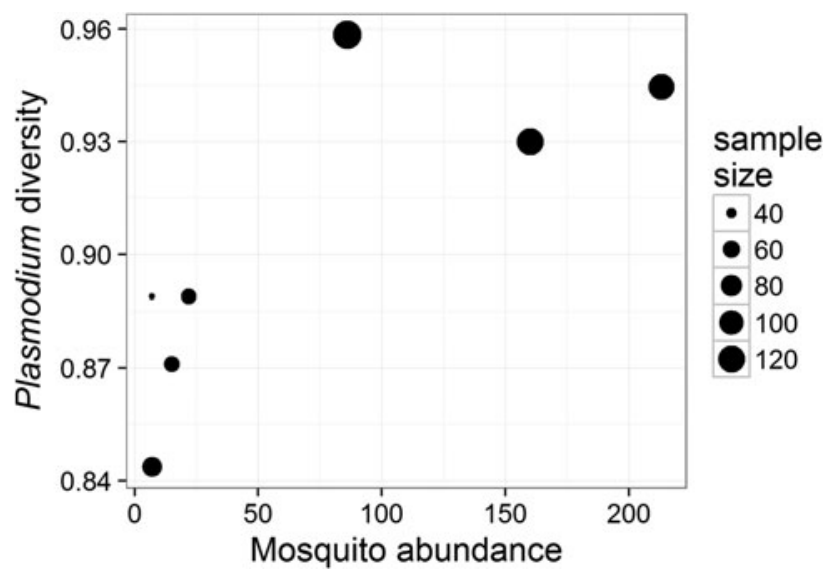

Fig. 3. Relationship between the diversity of Plasmodium parasites (calculated using Simpson's index of diversity) and mosquito abundance at each of the sampled sites; point size is scaled to the number of individual birds sampled at each site. The two variables are positively correlated $(\rho=0.79, P=0.034)$.

of Plasmodium parasites among avian hosts. None of the four ecological traits of avian hosts explained Plasmodium prevalence. The lack of seasonal differences in prevalence of Plasmodium found along the Tapajós River needs to be considered with caution since we tested this with samples collected from only two communities.

Our finding that Plasmodium lineage diversity is correlated with mosquito abundance and not with any avian host traits suggests that diversity and distribution of these parasites might be constrained by the final host (Culicidae) in our bird-parasite-mosquito system. Ishtiaq et al. (2008) demonstrated that the movement of Plasmodium lineages among southwest Pacific Islands might be restricted by the lack of overlap in the distributions of competent vector species. One possibility is that the mosquito community in our study region only has a few competent mosquito vectors and their signal was washed out by the huge mosquito diversity found in southeastern Amazonia. Alternatively, regional processes at the level of host populations, such as immunity to particular parasite lineages or differential exposure to certain parasite lineages, might mask any densitydependent influence of avian hosts and mosquitoes vectors on prevalence. For instance, the distribution and diversity of many parasites among host populations are known to be highly variable and one of the main reasons behind this is the inequality of individual host immune responses in defending themselves against particular parasites (Poulin, 2007).

Our results demonstrate that Plasmodium lineage diversity and prevalence in Amazonian birds does not vary with host ecological traits and avian host density. We expected that host population density would be positively correlated to avian malaria prevalence since it affects vector-host-encounter rates (Dobson, 2004). Although several studies 
have found evidence for higher haemosporidian prevalence in denser host populations (Matthews et al. 2016; Ricklefs et al. 2016; Ellis et al. 2017), many others failed to find such an association (Svensson-Coelho et al. 2013; Gonzalez-Quevedo et al. 2014). Kilpatrick et al. (2006) showed that West Nile virus transmission within a local host community was influenced by extreme heterogeneity in mosquito feeding patterns. At least in some sites, transmission of multi-host pathogens such as avian malaria, may be influenced by heterogeneity in host-vector compatibility more than by bird density (Kilpatrick et al. 2006; Medeiros et al. 2013). Specifically, for avian malaria, higher abundance of vectors does not lead to a higher host-vector-encounter rate. For example, Medeiros et al. (2015) showed that vectors overutilized some bird species regardless of their abundance and Plasmodium prevalence may be associated with vector utilization rather than vector abundance.

Nest characteristics among many other ecological traits of host individuals might be associated with variation in haemosporidian prevalence (Ricklefs et al. 2005; Fecchio et al. 2011, 2013; SvenssonCoelho et al. 2013; González et al. 2014; Lutz et al. 2015; Matthews et al. 2016). However, based on simple correlations, these studies relied on the premise that nestlings or adults are more exposed to the vectors in the nest according to its architecture. Moreover, mixed results found in these studies suggest that the relationship between nest type and risk of infection by haemosporidian parasites might be location dependent. An analysis of the identity of host blood found in engorged female mosquitoes could provide a general test for this pattern and confirm whether host nest type can predict haemosporidian prevalence in birds.

Lack of seasonal variation in Plasmodium prevalence found in two communities sampled along the Tapajós River confirms the temporal stability of these parasites in tropical birds. There are three main possible explanations for this: (1) the abundance of mosquito vectors might differ between seasons (i.e. site TL1), but even the lower number of actively feeding mosquitoes is sufficient to ensure transmission especially if these few mosquitoes are the most competent vector for more prevalent Plasmodium lineages; (2) infections in birds last long enough to span more than a single season and thus mask the changes in mosquito abundance between seasons; and (3) vector abundance might be stable over seasons (i.e. site TL2), allowing Plasmodium transmission throughout the year. If Plasmodium parasites have a dynamic aspect in tropical bird communities, it may vary with years or decades and not between seasons within the same year.

Several species of mosquito belonging to the genera Aedeomyia, Anopheles, Coquillettidia, Culex,
Culiseta, Mansonia, Aedes (Ochlerotatus and Stegomyia) have been implicated in the transmission of Plasmodium spp. in birds (Valkiūnas, 2005; Njabo et al. 2009). Among the species of mosquito inhabiting our study area in Tapajos, $A d$. (Ady.) squamipennis is known as a natural vector of avian malaria in Venezuela (Gabaldon et al. 1981). Another Neotropical mosquito Culex (Melanoconion) ocossa, together with $A d$. (Ady.) squamipennis could be responsible for the transmission of avian malaria in some regions of Panama (Loaiza and Miller, 2013). Unfortunately, we were not able to analyse the engorged females of these mosquitoes to study vectorial capacity or host specificity and thus future research on this is necessary as a first step to fully understand the transmission risk and high diversity of avian malaria parasites in the Neotropical region.

The absence of any perceivable pattern of host family within the phylogeny can be attributed to both the high level of sampling from the host family Thamnophilidae and the low level of host specificity known for Plasmodium (Beadell et al. 2004, 2009; Valkiūnas, 2005; Dimitrov et al. 2010; Ishtiaq et al. 2010). This low level of host specificity is shown in those lineages recovered from three and four different host families, spanning different host orders. Host switching is an important evolutionary mechanism in avian haemosporidian parasites with closely related haemosporidian lineages conserved within higher host taxa (Waldenström et al. 2002; Križanauskiené et al. 2006; Ricklefs et al. 2014). Due to high levels of host switching and subsequent dispersal, cospeciation is not thought to have played a large role in the evolutionary history of Plasmodium (Ricklefs et al. 2014; Lauron et al. 2015). However, the high host diversity in Amazonia would be an ideal system to explore the existence of coevolutionary links between Plasmodium parasites and avian hosts in future studies.

The heterogeneous prevalence of Plasmodium across bird species in southeastern Amazonia, regardless of their ecological traits, suggests that constraints on the distribution of these parasites are related to vectors within these assemblages. This highlights the importance of exposure to vectors in explaining avian malaria prevalence (Medeiros et al. 2015). Nonetheless, the results have to be interpreted cautiously, because of low sample sizes within sites and the low number of sites in general. Therefore, the next step in understanding the factors promoting the high diversity and heterogeneity of Plasmodium lineages in this region of Amazonia, as well as the mechanisms that produce variation in the prevalence of these vectorborne parasites across avian hosts, must include studies that integrate rates of vector exposure, feeding preference and vectorial capacity of the mosquitoes in the same area. 


\section{ACKNOWLEDGEMENTS}

We thank the ornithologists: Marcelo Barreiros, Gabriel Leite, Thiago Bicudo, Thiago Moura, Daniel Gressler, Camila Duarte and several Munduruku Indians who helped collect the blood samples. We also thank Camila Ribas and Mario Cohn-Haft from the Bird and Genetic Resources Collections of Instituto Nacional de Pesquisas da Amazônia who loaned the samples used in this study. We also thank three anonymous referees for their comments on earlier versions of the manuscript and Vitor Piacentini who kindly reviewed the bird nomenclature.

\section{FINANCIAL SUPPORT}

This work was funded by the Fundação de Amparo à Pesquisa do Estado do Amazonas - FAPEAM and Conselho Nacional de Desenvolvimento Científico e Tecnológico - CNPq (Process number 61.0012/2008.7DCR/CNPq/FAPEAM) to A.F. and US National Science Foundation grants DEB-1503804 to J.D.W. and DEB-1120734 to V.V.T. During the project, A.F. was supported by a postdoctoral fellowship from CNPq (Process numbers 350140/20120 and 201275/2014-7) and he is currently maintained by a PNPD scholarship from Coordenação de Aperfeiçoamento de Pessoal de Nível Superior (CAPES).

\section{REFERENCES}

Anderson, R. M. and May, R. M. (1978). Regulation and stability of host-parasite population interactions. I. Regulatory processes. Fournal of Animal Ecology 47, 219-247.

Beadell, J. S., Gering, E., Austin, J., Dumbacher, J. P., Peirce, M. A., Pratt, T. K., Atkinson, C. T. and Fleischer, R. C. (2004). Prevalence and differential host-specificity of two avian blood parasite genera in the Australo-Papuan region. Molecular Ecology 13, 3829-3844.

Beadell, J.S., Covas, R., Gebhard, C., Ishtiaq, F., Melo, M., Schmidt, B. K., Perkins, S. L., Graves, G. R. and Fleischer, R. C. (2009). Host associations and evolutionary relationships of avian blood parasites from West Africa. International Fournal for Parasitology 39, 257-266.

Bell, J. A., Weckstein, J. D., Fecchio, A. and Tkach, V. V. (2015). A new real-time PCR protocol for detection of avian haemosporidians. Parasites and Vectors 8, 383.

Bensch, S., Hellgren, O. and Pérez-Tris, J. (2009). MalAvi: a public database of malaria parasites and related haemosporidians in avian hosts based on mitochondrial cytochrome b lineages. Molecular Ecology Resources 9, 1353-1358.

Bolker, B. M., Brooks, M. E., Clark, C. J., Geange, S. W., Poulsen, J. R., Stevens, M.H.H. and White, J.-S.S. (2009). Generalized linear mixed models: a practical guide for ecology and evolution. Trends in Ecology and Evolution 24, 127-135.

Buckland, S. T., Anderson, D. R., Burnham, K. P., Laake, J. L., Borchers, D. L. and Thomas, L. (2001). Introduction to Distance Sampling: Estimating Abundance of Biological Populations. Oxford University Press, NY, USA.

Crawley, M. J. (2012). The R Book. John Wiley \& Sons, Ltd, Chichester, West Sussex, UK.

Darriba, D., Taboada, G. L., Doallo, R. and Posada, D. (2012). jModelTest 2: more models, new heuristics and parallel computing. Nature Methods $\mathbf{9}, 772$.

Dimitrov, D., Zehtindjiev, P. and Bensch, S. (2010). Genetic diversity of avian blood parasites in SE Europe: Cytochrome $b$ lineages of the genera Plasmodium and Haemoproteus (Haemosporida) from Bulgaria. Acta Parasitologica 55, 201-209.

Dobson, A. (2004). Population dynamics of pathogens with multiple host species. American Naturalist 164, S64-S78.

Drovetski, S. V., Aghayan, S. A., Mata, V. A., Lopes, R. J., Mode, N. A., Harvey, J. A. and Voelker, G. (2014). Does the niche breadth or trade-off hypothesis explain the abundance-occupancy relationship in avian Haemosporidia? Molecular Ecology 23, 3322-3329.

Ellis, V.A., Collins, M.D., Medeiros, M. C. I., Sari, E. H. R., Coffey, E. D., Dickerson, R. C., Lugarini, C., Stratford, J. A.,
Henry, D. R., Merrill, L., Matthews, A. E., Hanson, A. A., Roberts, J. R., Joyce, M., Kunkel, M. R. and Ricklefs, R. E. (2015). Local host specialization, host-switching, and dispersal shape the regional distributions of avian haemosporidian parasites. Proceedings of the National Academy of Sciences of the United States of America 112, 11294-11299.

Ellis, V.A., Medeiros, M. C.I., Collins, M. D., Sari, E.H. R., Coffey, E. D., Dickerson, R. D., Lugarini, C., Stratford, J. A., Henry, D. R., Merrill, M., Matthews, A.E., Hanson, A. A., Roberts, J. R., Joyce, M., Kunkel, M. R. and Ricklefs, R. E. (2017). Prevalence of avian haemosporidian parasites is positively related to the abundance of host species at multiple sites within a region. Parasitology Research 116, 73-80.

Falcão, A. R. (1981). Um novo modelo de armadilha luminosa de sucção para pequenos insetos. Memórias do Instituto Oswaldo Cruz 76, 303-305. Fecchio, A., Lima, M. R., Silveira, P., Braga, É. M. and Marini, M. Â. (2011). High prevalence of blood parasites in social birds from a neotropical savanna in Brazil. Emu 111, 132-138.

Fecchio, A., Lima, M. R., Svensson-Coelho, M., Marini, M. Â. and Ricklefs, R. E. (2013). Structure and organization of an avian haemosporidian assemblage in a Neotropical savanna in Brazil. Parasitology 140, 181-192.

Forattini, O. P. (1962). Entomologia Médica, Vol. 1. Edusp, São Paulo, SP, Brazil.

Forattini, O.P. (1965a). Entomologia Médica, Vol.2. Edusp, São Paulo, SP, Brazil.

Forattini, O.P. (1965b). Entomologia Médica, Vol. 3. Edusp, São Paulo, SP, Brazil.

Forattini, O.P. (2002). Culicidologia Médica, Vol. 2. Identificação, Biologia, Epidemiologia. Editora da Universidade de São Paulo, São Paulo, SP, Brazil.

Gabaldon, A. U., Ulloa, G. and Pulido, J. (1981). Distribucion geografica, ecologia y etologia de Aedeomyia squamipennis, importante vector natural de malaria aviaria en Venezuela. Boletin de la Dirección de Malariología y Saneamiento Ambiental 21, 103-113.

Galindo, P., Blanton, F. S. and Peyton, E. L. (1954). A revision of the Uranotaenia of Panama with notes on other American species of the genus (Diptera, Culicidae). Annals of the Entomological Society of America 47, 107-177.

González, A. D., Matta, N. E., Ellis, V. A., Miller, E. T., Ricklefs, R. E. and Gutiérrez, H. R. (2014). Mixed species flock, nest height, and elevation partially explain avian haemoparasite prevalence in Colombia. PLoS ONE 9, e100695.

Gonzalez-Quevedo, C., Davies, R. G. and Richardson, D. S. (2014) Predictors of malaria infection in a wild bird population: landscape-level analyses reveal climatic and anthropogenic factors. Fournal of Animal Ecology 83, 1091-1102.

Guernier, V., Hochberg, M. E. and Guégan, J-F. (2004). Ecology drives the worldwide distribution of human diseases. PLoS Biology 2, e141.

Hall, T. A. (1999). BIOEDIT: a user-friendly biological sequence alignment editor and analysis program for Windows 95/98/NT. Nucleic Acids Symposium Series 41, 95-98.

Harbach, R. (2013). Mosquito Taxonomic Inventory. www.mosquitotaxonomic-inventory.info/.

Harrigan, R. J., Sedano, R., Chasar, J. A., Nguyen, J. T., Whitaker, A. and Smith, T. B. (2014). New host and lineage diversity of avian haemosporidians in the northern Andes. Evolutionary Applications 7, 799-811.

Huelsenbeck, J.P. and Ronquist, F. (2001). MRBAYES: Bayesian inference and phylogeny. Bioinformatics 17, 754-755.

Ishtiaq, F., Guillaumot, L., Clegg, S. M., Phillimore, A. B., Black, R. A., Owens, I. P.F., Mundy, N. I. and Sheldon, B. C. (2008). Avian haematozoan parasites and their associations with mosquitoes across Southwest Pacific Islands. Molecular Ecology 17, 4545-4555.

Ishtiaq, F., Clegg, S. M., Phillimore, A. B., Black, R. A., Owens, I. P. F. and Sheldon, B. C. (2010). Biogeographical patterns of blood parasite lineage diversity in avian hosts from southern Melanesian islands. Fournal of Biogeography 37, 120-132.

Kamiya, T., O'Dwyer, K., Nakagawa, S. and Poulin, P. (2014). What determines species richness of parasitic organisms? A meta-analysis across animal, plant and fungal hosts. Biological Reviews 89, 123-134.

Kilpatrick, A. M., Daszak, P., Jones, M. J., Marra, P.P. and

Kramer, L. D. (2006). Host heterogeneity dominates West Nile virus transmission. Proceedings of the Royal Society of London B: Biological Sciences 273, 2327-2333.

Križanauskiené, A., Hellgren, O., Kosarev, V., Sokolov, L., Bensch, S. and Valkiūnas, G. (2006). Variation in host specificity between species of avian hemosporidian parasites: evidence from parasite morphology and cytochrome $b$ gene sequences. Fournal of Parasitology 92, 1319-1324. 
LaPointe, D. A., Goff, M. L. and Atkinson, C. T. (2010). Thermal constraints to the sporogonic development and altitudinal distribution of avian malaria Plasmodium relictum in Hawaii. Fournal of Parasitology 96, 318-324.

Lauron, E. J., Loiseau, C., Bowie, R. C. K., Spicer, G. S., Smith, T. B., Melo, M. and Sehgal, R. N.M. (2015). Coevolutionary patterns and diversification of avian malaria parasites in African sunbirds (Family Nectariniidae). Parasitology 142, 635-647.

Lesnoff, M. and Lancelot, R. (2012). aod: Analysis of Overdispersed Data. R package Version 1.3. http://cran.r-project.org/package $=$ aod

Loaiza, J. R. and Miller, M. J. (2013). Seasonal pattern of avian Plasmodium-infected mosquitoes and implications for parasite transmission in central Panama. Parasitology Research 112, 3743-3751.

Lutz, H. L., Hochachka, W. M., Engel, J. I., Bell, J. A., Tkach, V. V., Bates, J. M., Hackett, S. J. and Weckstein, J. D. (2015). Parasite prevalence corresponds to host life history in a diverse assemblage of Afrotropical birds and haemosporidian parasites. PLoS ONE 10, e0121254.

Matthews, A. E., Ellis, V. A., Hanson, A. A., Roberts, J. R., Ricklefs, R. E. and Collins, M. D. (2016). Avian haemosporidian prevalence and its relationship to host life histories in eastern Tennessee. Fournal of Ornithology 157, 533-548.

McKeon, S. N., Moreno, M., Sallum, M. A. M., Povoa, M. M. and Conn, J.E. (2013). Distinct population structure for co-occurring Anopheles goeldii and Anopheles triannulatus in Amazonian Brazil. Memórias do Instituto Oswaldo Cruz 108, 605-615.

Medeiros, M. C. I., Hamer, G. L. and Ricklefs, R. E. (2013). Host compatibility rather than vector-host encounter rate determines the host range of avian Plasmodium parasites. Proceedings of the Royal Society of London B: Biological Sciences 280, 20122947.

Medeiros, M. C. I., Ricklefs, R. E., Brawn, J. D. and Hamer, G. L. (2015). Plasmodium prevalence across avian host species is positively associated with exposure to mosquito vectors. Parasitology 142, 16121620

Moreno, M., Bickersmith, S., Harlow, W., Hildebrandt, J., McKeon, S. N., Silva-do-Nascimento, T. F., Loaiza, J. R., Ruiz, F., Lourenço-de-Oliveira, R., Sallum, M. A., Bergo, E. S., Fritz, G. N., Wilkerson, R. C., Linton, Y.M., Juri, M. J., Range1, Y., Póvoa, M. M., Gutiérrez-Builes, L. A., Correa, M. M. and Conn, J. E. (2013). Phylogeography of the neotropical Anopheles triannulatus complex (Diptera: Culicidae) supports deep structure and complex patterns. Parasites and Vectors 6, 47

Njabo, K.Y., Cornel, A. J., Sehgal, R. N.M., Loiseau, C., Buermann, W., Harrigan, R. J., Pollinger, J., Valkiūnas, G. and Smith, T.B. (2009). Coquillettidia (Culicidae, Diptera) mosquitoes are natural vectors of avian malaria in Africa. Malaria Fournal 8, 193

Nunn, C. L. and·Heymann, E. W. (2005). Malaria infection and host behavior: a comparative study of Neotropical primates. Behavioral Ecology and Sociobiology 50, 30-37.

Nunn, C. L., Altizer, S. M., Sechrest, W. and Cunningham, A. A. (2005). Latitudinal gradients of parasite species richness in primates. Diversity and Distributions 11, 249-256.

Oakgrove, K. S., Harrigan, R. J., Loiseau, C., Guers, S., Seppi, B. and Sehgal, R. N. M. (2014). Distribution, diversity and drivers of bloodborne parasite co-infections in Alaskan bird populations. International Fournal for Parasitology 44, 717-727.

Okanga, S., Cumming, G. S. and Hockey, P.A. R. (2013). Avian malaria prevalence and mosquito abundance in the Western Cape, South Africa. Malaria Fournal 12, 370.

Oksanen, J., Blanchet, F. G., Kindt, R., Legendre, P., Minchin, P. R., O'Hara, R. B., Simpson, G. L., Solymos, P., Stevens, M.H.H. and Wagner, H. (2015). Vegan: Community Ecology Package. R Package Version 2.2-1.

Piacentini, V. Q., Aleixo, A., Agne, C.E., Maurício, G. N., Pacheco, J. F., Bravo, G. A., Brito, G. R. R., Naka, L. N., Olmos, F., Posso, S., Silveira, L.F., Betini, G.S., Carrano, E., Franz, I., Lees, A. C., Lima, L. M., Pioli, D., Schunck, F., Amaral, F. R., Bencke, G. A., Cohn-Haft, M., Figueiredo, L.F. A., Straube, F. C. and Cesari, E. (2015). Annotated checklist of the birds of Brazil by the Brazilian Ornithological Records Committee/Lista comentada das aves do Brasil pelo Comitê Brasileiro de Registros Ornitológicos. Revista Brasileira de Ornitologia 23, 91-298.
Poulin, R. (1997). Species richness of parasite assemblages: evolution and patterns. Annual Review of Ecology and Systematics 28, 341-358.

Poulin, R. (2007). Evolutionary Ecology of Parasites. Princeton University Press, Princeton, NJ, USA.

Rambaut, A. (2009). Figtree. http://tree.bio.ed.ac.uk/software/figtree/.

R Core Team (2015). R: A language and Environment for Statistical Computing. R Foundation for Statistical Computing, Vienna, Austria. Reinert, J. F. (2001). Revised list of abbreviations for genera and subgenera of Culicidae (Diptera) and notes on generic and subgeneric changes. Fournal of the American Mosquito Control Association 17, 51-55.

Ricklefs, R. E., Swanson, B. L., Fallon, S. M., Martinez-Abrain, A., Scheuerlein, A., Gray, J. and Latta, S. C. (2005). Community relationships of avian malaria parasites in southern Missouri. Ecological Monographs 75, 543-559.

Ricklefs, R. E., Outlaw, D. C., Svensson-Coelho, M., Medeiros, M. C. I., Ellis, V. A. and Latta, S. (2014). Species formation by host shifting in avian malaria parasites. Proceedings of the National Academy of Sciences of the United States of America 111, 14816-14821.

Ricklefs, R. E., Soares, L., Ellis, V. A. and Latta, S. C. (2016). Haemosporidian parasites and avian host population abundance in the Lesser Antilles. Fournal of Biogeography 43, 1277-1286.

Ridgely, R.S. and Tudor, G. (1989a). The Birds of South America: Vol. I: The Oscine Passerines. University of Texas Press, Austin, TX, USA. Ridgely, R. S. and Tudor, G. (1989b). The Birds of South America: Vol. II: The Suboscine Passerines. University of Texas Press, Austin, TX, USA. Rohde, K. and Heap, M. (1998). Latitudinal differences in species and community richness and in community structure of metazoan endo- and ectoparasites of marine teleost fish. International Yournal for Parasitology 28, 461-474.

Ronquist, F. and Huelsenbeck, J. P. (2003). MRBAYES 3: Bayesian phylogenetic inference under mixed models. Bioinformatics 19, 1572-1574. Ruiz-Lopez, F., Wilkerson, R. C., Ponsonby, D. J., Herrera, M., Sallum, M. A., Velez, I. D., Quiñones, M.L., Flores-Mendoza, C., Chadee, D. D., Alarcon, J., Alarcon-Ormasa, J. and Linton, Y. M. (2013). Systematics of the oswaldoi complex (Anopheles, Nyssorhynchus) in South America. Parasites and Vectors 6, 324.

Santiago-Alarcon, D., Palinauskas, V. and Schaefer, H. M. (2012). Diptera vectors of avian Haemosporidian parasites: untangling parasite life cycles and their taxonomy. Biological Reviews 87, 928-964.

Silva, J. M. C., Rylands, A. B. and Fonseca, G. A. B. (2005). The fate of the amazonian areas of endemism. Conservation Biology 19, 689-694.

Stephens, M. and Donnelly, P. (2003). A comparison of Bayesian methods for haplotype reconstruction from population genotype data. American Yournal of Human Genetics 73, 1162-1169.

Stephens, M., Smith, N. J. and Donnelly, P. (2001). A new statistical method for haplotype reconstruction from population data. American Fournal of Human Genetics 68, 978-989.

Stotz, D. F., Fitzpatrick, J. W., Parker, T. A. and Moskovits, D. K. (1996). Neotropical birds: Ecology and Conservation. The University of Chicago Press, Chicago, IL, USA.

Svensson-Coelho, M., Blake, J. G., Loiselle, B. A., Penrose, A. S., Parker, P. G. and Ricklefs, R. E. (2013). Diversity, prevalence, and host specificity of avian Plasmodium and Haemoproteus in a Western Amazon assemblage. Ornithological Monographs 76, 1-47.

Thomas, L., Laake, J. L., Rexstad, E. A., Strindberg, S., Marques, F. F. C., Buckland, S. T., Borchers, D. L., Anderson, D. R., Burnham, K. P., Burt, M. L., Hedley, S. L., Pollard, J. H., Bishop, J. R. B. and Marques, T.A. (2009). Distance 6.0. Release 2. Research Unit for Wildlife Population Assessment, University of St. Andrews, St. Andrews, Fife, UK. http://www.ruwpa.st-and.ac.uk/distance.

Valkiūnas, G. (2005). Avian Malaria Parasites and Other Haemosporidian. CRC Press, Boca Raton, FL, USA.

Villesen, P. (2007). FaBox: an online toolbox for fasta sequences. Molecular Ecology Notes 7, 965-968.

Waldenström, J., Bensch, S., Kiboi, S., Hasselquist, D. and Ottoson, U. (2002). Cross-species infection of blood parasites between resident and migratory songbirds in Africa. Molecular Ecology 11, 1545-1554.

Wood, M. J., Cosgrove, C. L., Wilkin, T. A., Knowles, S. C. L., Day, K. P. and Sheldon, B. C. (2007). Within-population variation in prevalence and lineage distribution of avian malaria in blue tits, Cyanistes caeruleus. Molecular Ecology 16, 3263-3273. 
APPENDIX

Table A1. Plasmodium prevalence from seven bird communities in southeastern Amazonia, Brazil. Species of birds are organized taxonomically

\begin{tabular}{|c|c|c|c|c|c|}
\hline Order & Family & Scientific name & $\begin{array}{c}\text { Sampled } \\
\text { individuals }\end{array}$ & Infected & Prevalence $(\%)$ \\
\hline Accipitriformes & Accipitridae & Leucopternis melanops & 1 & 0 & 0 \\
\hline Columbiformes & Columbidae & Leptotila rufaxilla & 5 & 0 & 0 \\
\hline Columbiformes & Columbidae & Geotrygon montana & 4 & 0 & 0 \\
\hline Apodiformes & Trochilidae & Glaucis hirsutus & 3 & 0 & 0 \\
\hline Apodiformes & Trochilidae & Threnetes leucurus & 1 & 0 & 0 \\
\hline Apodiformes & Trochilidae & Phaethornis superciliosus insignis & 4 & 1 & 25 \\
\hline Apodiformes & Trochilidae & Phaethornis sp. & 1 & 1 & 100 \\
\hline Apodiformes & Trochilidae & Campylopterus largipennis & 1 & 0 & 0 \\
\hline Trogoniformes & Trogonidae & Trogon collaris & 1 & 0 & 0 \\
\hline Coraciiformes & Alcedinidae & Chloroceryle aenea & 4 & 0 & 0 \\
\hline Coraciiformes & Momotidae & Baryphthengus martii & 1 & 0 & 0 \\
\hline Galbuliformes & Galbulidae & Galbula cyanicollis & 9 & 5 & $55 \cdot 6$ \\
\hline Galbuliformes & Galbulidae & Facamerops aureus & 1 & 0 & 0 \\
\hline Galbuliformes & Bucconidae & Malacoptila rufa & 5 & 0 & 0 \\
\hline Galbuliformes & Bucconidae & Monasa nigrifrons & 3 & 1 & $33 \cdot 3$ \\
\hline Piciformes & Ramphastidae & Ramphastos vitellinus & 1 & 0 & 0 \\
\hline Piciformes & Picidae & Veniliornis affinis & 1 & 0 & 0 \\
\hline Piciformes & Picidae & Celeus elegans & 5 & 0 & 0 \\
\hline Falconiformes & Falconidae & Micrastur ruficollis & 1 & 0 & 0 \\
\hline Falconiformes & Falconidae & Micrastur semitorquatus & 1 & 1 & 100 \\
\hline Passeriformes & Thamnophilidae & Myrmornis torquata & 5 & 2 & 40 \\
\hline Passeriformes & Thamnophilidae & Epinecrophylla leucophthalma & 15 & 0 & 0 \\
\hline Passeriformes & Thamnophilidae & Epinecrophylla sp. & 1 & 1 & 100 \\
\hline Passeriformes & Thamnophilidae & Myrmotherula axillaris & 19 & 6 & $31 \cdot 6$ \\
\hline Passeriformes & Thamnophilidae & Myrmotherula longipennis & 17 & 5 & $29 \cdot 4$ \\
\hline Passeriformes & Thamnophilidae & Myrmotherula menetriesii & 1 & 1 & 100 \\
\hline Passeriformes & Thamnophilidae & Isleria hauxwelli & 19 & 4 & $21 \cdot 1$ \\
\hline Passeriformes & Thamnophilidae & Thamnomanes saturninus & 25 & 10 & 40 \\
\hline Passeriformes & Thamnophilidae & Thamnomanes caesius & 9 & 3 & $33 \cdot 3$ \\
\hline Passeriformes & Thamnophilidae & Dichrozona cincta & 5 & 2 & 40 \\
\hline Passeriformes & Thamnophilidae & Thamnophilus schistaceus & 4 & 2 & 50 \\
\hline Passeriformes & Thamnophilidae & Thamnophilus nigrocinereus & 11 & 7 & $63 \cdot 6$ \\
\hline Passeriformes & Thamnophilidae & Thamnophilus aethiops & 4 & 1 & 25 \\
\hline Passeriformes & Thamnophilidae & Thamnophilus amazonicus & 1 & 1 & 100 \\
\hline Passeriformes & Thamnophilidae & Myrmoderus ferrugineus & 1 & 0 & 0 \\
\hline Passeriformes & Thamnophilidae & Hypocnemoides maculicauda & 10 & 0 & 0 \\
\hline Passeriformes & Thamnophilidae & Hylophylax naevius & 6 & 1 & $16 \cdot 7$ \\
\hline Passeriformes & Thamnophilidae & Hylophylax punctulatus & 5 & 1 & 20 \\
\hline Passeriformes & Thamnophilidae & Myrmelastes leucostigma & 2 & 1 & 50 \\
\hline Passeriformes & Thamnophilidae & Myrmoborus myotherinus & 22 & 9 & $40 \cdot 9$ \\
\hline Passeriformes & Thamnophilidae & Cercomacroides nigrescens & 2 & 0 & 0 \\
\hline Passeriformes & Thamnophilidae & Hypocnemis striata & 32 & 17 & $53 \cdot 1$ \\
\hline Passeriformes & Thamnophilidae & Willisornis poecilinotus & 14 & 7 & 50 \\
\hline Passeriformes & Thamnophilidae & Phlegopsis nigromaculata & 28 & 11 & $39 \cdot 3$ \\
\hline Passeriformes & Thamnophilidae & Rhegmatorhina gymnops & 4 & 1 & 25 \\
\hline Passeriformes & Thamnophilidae & Rhegmatorhina berlepschi & 12 & 1 & $8 \cdot 3$ \\
\hline Passeriformes & Conopophagidae & Conopophaga aurita & 4 & 1 & 25 \\
\hline Passeriformes & Formicariidae & Formicarius colma & 5 & 1 & 20 \\
\hline Passeriformes & Formicariidae & Formicarius analis & 1 & 0 & 0 \\
\hline Passeriformes & Scleruridae & Sclerurus macconnelli & 2 & 0 & 0 \\
\hline Passeriformes & Scleruridae & Sclerurus caudacutus & 2 & 0 & 0 \\
\hline Passeriformes & Dendrocolaptidae & Dendrocincla fuliginosa & 5 & 0 & 0 \\
\hline Passeriformes & Dendrocolaptidae & Dendrocincla merula & 14 & 0 & 0 \\
\hline Passeriformes & Dendrocolaptidae & Deconychura longicauda & 5 & 0 & 0 \\
\hline Passeriformes & Dendrocolaptidae & Sittasomus griseicapillus & 1 & 0 & 0 \\
\hline Passeriformes & Dendrocolaptidae & Certhiasomus stictolaemus & 3 & 0 & 0 \\
\hline Passeriformes & Dendrocolaptidae & Glyphorynchus spirurus & 26 & 0 & 0 \\
\hline Passeriformes & Dendrocolaptidae & Xiphorhynchus ocellatus & 1 & 0 & 0 \\
\hline Passeriformes & Dendrocolaptidae & Xiphorhynchus elegans & 18 & 0 & 0 \\
\hline Passeriformes & Dendrocolaptidae & Xiphorhynchus obsoletus & 4 & 0 & 0 \\
\hline
\end{tabular}


Table A1. (Cont.)

\begin{tabular}{|c|c|c|c|c|c|}
\hline Order & Family & Scientific name & $\begin{array}{l}\text { Sampled } \\
\text { individuals }\end{array}$ & Infected & Prevalence $(\%)$ \\
\hline Passeriformes & Dendrocolaptidae & Xiphorhynchus guttatus & 2 & 0 & 0 \\
\hline Passeriformes & Dendrocolaptidae & Campylorhamphus procurvoides & 1 & 0 & 0 \\
\hline Passeriformes & Dendrocolaptidae & Dendroplex picus & 4 & 0 & 0 \\
\hline Passeriformes & Dendrocolaptidae & Dendrocolaptes certhia & 3 & 1 & $33 \cdot 3$ \\
\hline Passeriformes & Xenopidae & Xenops minutus & 8 & 1 & $12 \cdot 5$ \\
\hline Passeriformes & Furnariidae & Automolus rufipileatus & 2 & 0 & 0 \\
\hline Passeriformes & Furnariidae & Automolus subulatus & 1 & 0 & 0 \\
\hline Passeriformes & Furnariidae & Automolus ochrolaemus & 11 & 2 & $18 \cdot 2$ \\
\hline Passeriformes & Furnariidae & Automolus paraensis & 3 & 1 & $33 \cdot 3$ \\
\hline Passeriformes & Furnariidae & Philydor erythrocercum & 2 & 0 & 0 \\
\hline Passeriformes & Furnariidae & Philydor pyrrhodes & 5 & 0 & 0 \\
\hline Passeriformes & Furnariidae & Synallaxis rutilans & 3 & 0 & 0 \\
\hline Passeriformes & Furnariidae & Cranioleuca vulpina & 2 & 1 & 50 \\
\hline Passeriformes & Pipridae & Pipra fasciicauda & 2 & 2 & 100 \\
\hline Passeriformes & Pipridae & Ceratopipra rubrocapilla & 18 & 0 & 0 \\
\hline Passeriformes & Pipridae & Lepidothrix nattereri & 23 & 0 & 0 \\
\hline Passeriformes & Pipridae & Lepidothrix vilasboasi & 3 & 1 & $33 \cdot 3$ \\
\hline Passeriformes & Pipridae & Lepidothrix iris & 1 & 0 & 0 \\
\hline Passeriformes & Pipridae & Heterocercus linteatus & 13 & 0 & 0 \\
\hline Passeriformes & Pipridae & Dixiphia pipra & 2 & 0 & 0 \\
\hline Passeriformes & Pipridae & Chiroxiphia pareola & 1 & 0 & 0 \\
\hline Passeriformes & Onychorhynchidae & Onychorhynchus coronatus & 8 & 0 & 0 \\
\hline Passeriformes & Onychorhynchidae & Terenotriccus erythrurus & 2 & 1 & 50 \\
\hline Passeriformes & Onychorhynchidae & Myiobius barbatus & 4 & 1 & 25 \\
\hline Passeriformes & Tityridae & Schiffornis turdina & 8 & 1 & $12 \cdot 5$ \\
\hline Passeriformes & Cotingidae & Lipaugus vociferans & 1 & 0 & 0 \\
\hline Passeriformes & Platyrinchidae & Platyrinchus saturatus & 1 & 0 & 0 \\
\hline Passeriformes & Platyrinchidae & Platyrinchus platyrhynchos & 6 & 0 & 0 \\
\hline Passeriformes & Rhynchocyclidae & Mionectes oleagineus & 6 & 1 & $16 \cdot 7$ \\
\hline Passeriformes & Rhynchocyclidae & Mionectes macconnelli & 4 & 2 & 50 \\
\hline Passeriformes & Rhynchocyclidae & Leptopogon amaurocephalus & 1 & 1 & 100 \\
\hline Passeriformes & Rhynchocyclidae & Corythopis torquatus & 1 & 0 & 0 \\
\hline Passeriformes & Rhynchocyclidae & Rhynchocyclus olivaceus & 2 & 0 & 0 \\
\hline Passeriformes & Rhynchocyclidae & Tolmomyias sulphurescens & 2 & 0 & 0 \\
\hline Passeriformes & Rhynchocyclidae & Tolmomyias flaviventris & 1 & 0 & 0 \\
\hline Passeriformes & Tyrannidae & Attila spadiceus & 5 & 1 & 20 \\
\hline Passeriformes & Tyrannidae & Ramphotrigon ruficauda & 2 & 0 & 0 \\
\hline Passeriformes & Tyrannidae & Myiarchus ferox & 1 & 1 & 100 \\
\hline Passeriformes & Tyrannidae & Myiarchus sp. & 1 & 0 & 0 \\
\hline Passeriformes & Tyrannidae & Rhytipterna simplex & 5 & 0 & 0 \\
\hline Passeriformes & Tyrannidae & Cnemotriccus fuscatus & 5 & 0 & 0 \\
\hline Passeriformes & Tyrannidae & Knipolegus poecilocercus & 6 & 0 & 0 \\
\hline Passeriformes & Vireonidae & Hylophilus semicinereus & 1 & 0 & 0 \\
\hline Passeriformes & Vireonidae & Tunchiornis ochraceiceps & 6 & 1 & $16 \cdot 7$ \\
\hline Passeriformes & Troglodytidae & Microcerculus marginatus & 2 & 0 & 0 \\
\hline Passeriformes & Troglodytidae & Pheugopedius genibarbis & 3 & 1 & $33 \cdot 3$ \\
\hline Passeriformes & Troglodytidae & Cantorchilus leucotis & 11 & 4 & $36 \cdot 4$ \\
\hline Passeriformes & Polioptilidae & Ramphocaenus melanurus & 1 & 0 & 0 \\
\hline Passeriformes & Turdidae & Turdus fumigatus & 7 & 2 & $28 \cdot 6$ \\
\hline Passeriformes & Turdidae & Turdus albicollis & 3 & 0 & 0 \\
\hline Passeriformes & Passerellidae & Arremon taciturnus & 4 & 2 & 50 \\
\hline Passeriformes & Thraupidae & Coryphospingus cucullatus & 1 & 0 & 0 \\
\hline Passeriformes & Thraupidae & Lanio surinamus & 3 & 0 & 0 \\
\hline Passeriformes & Thraupidae & Lanio cristatus & 2 & 1 & 50 \\
\hline Passeriformes & Thraupidae & Ramphocelus carbo & 11 & 2 & $18 \cdot 2$ \\
\hline Passeriformes & Thraupidae & Sporophila angolensis & 5 & 0 & 0 \\
\hline Passeriformes & Thraupidae & Saltator maximus & 2 & 0 & 0 \\
\hline Passeriformes & Thraupidae & Saltator coerulescens & 5 & 0 & 0 \\
\hline Passeriformes & Thraupidae & Saltator grossus & 2 & 0 & 0 \\
\hline \multirow[t]{2}{*}{ Passeriformes } & Cardinalidae & Cyanoloxia rothschildii & 6 & 0 & 0 \\
\hline & & & 675 & 136 & $20 \cdot 1$ \\
\hline
\end{tabular}


Table A2. The 11 bird species used to test the effect of host density (individuals per 100 ha) on prevalence of Plasmodium from three transects along the Tapajós River. The geographic locations of sites can be found in Fig. 1

\begin{tabular}{llcrr}
\hline \hline & & Sampled & & \\
Species & Location & individuals & Infected & Density \\
\hline Ceratopipra rubrocapilla & TL2 & 5 & 0 & $17 \cdot 29$ \\
Galbula cyanicollis & TL1 & 6 & 4 & $1 \cdot 99$ \\
Glyphorynchus spirurus & TL1 & 5 & 0 & $6 \cdot 95$ \\
& TL2 & 8 & 0 & $11 \cdot 12$ \\
Hypocnemis striata & TL3 & 5 & 0 & $8 \cdot 34$ \\
& TL1 & 9 & 6 & $12 \cdot 46$ \\
Lepidothrix nattereri & TL3 & 10 & 8 & $38 \cdot 53$ \\
& TL1 & 7 & 0 & $5 \cdot 75$ \\
Myrmoborus myotherinus & TL2 & 9 & 0 & $6 \cdot 79$ \\
Myrmotherula axillaris & TL1 & 6 & 3 & $6 \cdot 27$ \\
Myrmotherula longipennis & TL3 & 5 & 3 & $18 \cdot 91$ \\
Phlegopsis nigromaculata & TL1 & 5 & 1 & $29 \cdot 32$ \\
& TL1 & 5 & 5 & $11 \cdot 05$ \\
Willisornis poecilinotus & TL1 & 6 & 2 & $1 \cdot 65$ \\
Xiphorhynchus elegans & TL2 & 5 & 1 & $2 \cdot 23$ \\
& TL2 & 5 & 0 & $11 \cdot 18$ \\
& TL2 & 7 & 0 & $0 \cdot 00$ \\
& TL3 & 6 & 37 & $12 \cdot 13$ \\
\hline \hline
\end{tabular}

Table A3. In the main text of our paper we report the results of a multiple regression (GLM) modelling prevalence as a function of four explanatory variables (nest location, nest type, flocking and diet). Here we report the results of four separate models of each explanatory variable by itself, for comparison. Each model is a GLM with a 'quasibinomial' error structure (to account for overdispersion as in the model presented in the main text); coefficients are reported as in Table 2 of the main text

\begin{tabular}{|c|c|c|c|c|}
\hline & $\begin{array}{c}\text { Estimate of } \\
\text { coefficient }\end{array}$ & S.E. & $t$ value & $P$ \\
\hline \multicolumn{5}{|l|}{ Model 1 - nest location } \\
\hline Intercept & -0.571 & $0 \cdot 732$ & $-0 \cdot 78$ & $0 \cdot 44$ \\
\hline Understory & $-0 \cdot 413$ & $0 \cdot 808$ & $-0 \cdot 511$ & $0 \cdot 613$ \\
\hline Sub canopy & $-1 \cdot 025$ & $0 \cdot 849$ & $-1 \cdot 208$ & $0 \cdot 234$ \\
\hline Canopy & $-1 \cdot 221$ & $1 \cdot 354$ & $-0 \cdot 902$ & $0 \cdot 373$ \\
\hline Cliff or Bank & $-0 \cdot 528$ & $1 \cdot 871$ & $-0 \cdot 282$ & $0 \cdot 779$ \\
\hline \multicolumn{5}{|l|}{ Model 2 - nest type } \\
\hline Intercept & -0.952 & $0 \cdot 269$ & $-3 \cdot 538$ & $0 \cdot 001$ \\
\hline Closed cup & $-0 \cdot 735$ & $1 \cdot 019$ & $-0 \cdot 722$ & $0 \cdot 475$ \\
\hline Cavity & $-0 \cdot 879$ & $0 \cdot 592$ & $-1 \cdot 485$ & $0 \cdot 145$ \\
\hline \multicolumn{5}{|l|}{ Model 3 - flocking } \\
\hline Intercept & $-1 \cdot 225$ & $0 \cdot 335$ & $-3 \cdot 661$ & $0 \cdot 001$ \\
\hline Single species & $-1 \cdot 26$ & $1 \cdot 522$ & $-0 \cdot 828$ & $0 \cdot 412$ \\
\hline Mixed species & $0 \cdot 14$ & $0 \cdot 468$ & $0 \cdot 298$ & $0 \cdot 767$ \\
\hline \multicolumn{5}{|l|}{ Model 4 - diet } \\
\hline Intercept & $-0 \cdot 931$ & $0 \cdot 221$ & $-4 \cdot 217$ & $0 \cdot 0001$ \\
\hline Frugivore/Granivore & $-18 \cdot 061$ & $2417 \cdot 171$ & $-0 \cdot 007$ & $0 \cdot 994$ \\
\hline Omnivore & $-1 \cdot 503$ & $0 \cdot 878$ & $-1 \cdot 711$ & $0 \cdot 095$ \\
\hline
\end{tabular}


Table A4. The 44 species used in the analysis of an effect of avian ecological traits on Plasmodium prevalence in southeastern Amazonia

\begin{tabular}{|c|c|c|c|c|c|c|}
\hline \multirow[b]{2}{*}{ Specie name } & \multicolumn{2}{|c|}{$\begin{array}{l}\text { Number of } \\
\text { individuals }\end{array}$} & \multicolumn{4}{|c|}{ Ecological traits analysed } \\
\hline & Sampled & Infected & Nest location & Nest type & Flocking & Diet \\
\hline Attila spadiceus & 5 & 1 & Understory & Open cup & Solitary/family & Insectivore \\
\hline Automolus ochrolaemus & 11 & 2 & Cliff or Bank & Cavity & Mixed species & Insectivore \\
\hline Cantorchilus leucotis & 11 & 4 & Understory & Closed cup & Solitary/family & Insectivore \\
\hline Celeus elegans & 5 & 0 & Sub canopy & Cavity & Solitary/family & Omnivore \\
\hline Ceratopipra rubrocapilla & 18 & 0 & Understory & Open cup & Solitary/family & $\begin{array}{c}\text { Frugivore/ } \\
\text { Granivore }\end{array}$ \\
\hline Cyanoloxia rothschildii & 6 & 0 & Understory & Open cup & Solitary/family & Omnivore \\
\hline Deconychura longicauda & 5 & 0 & Sub canopy & Cavity & Mixed species & Insectivore \\
\hline Dendrocincla fuliginosa & 5 & 0 & Sub canopy & Cavity & Mixed species & Insectivore \\
\hline Dendrocincla merula & 14 & 0 & Sub canopy & Cavity & Mixed species & Insectivore \\
\hline Epinecrophylla leucophthalma & 15 & 0 & Understory & Open cup & Single species & Insectivore \\
\hline Formicarius colma & 5 & 1 & Understory & Cavity & Mixed species & Insectivore \\
\hline Galbula cyanicollis & 9 & 5 & Sub canopy & Cavity & Mixed species & Insectivore \\
\hline Glyphorynchus spirurus & 26 & 0 & Sub canopy & Cavity & Mixed species & Insectivore \\
\hline Heterocercus linteatus & 13 & 0 & Understory & Open cup & Solitary/family & $\begin{array}{c}\text { Frugivore/ } \\
\text { Granivore }\end{array}$ \\
\hline Hylophylax naevius & 6 & 1 & Understory & Open cup & Solitary/family & Insectivore \\
\hline Hylophylax punctulatus & 5 & 1 & Understory & Open cup & Solitary/family & Insectivore \\
\hline Hypocnemis striata & 32 & 17 & Understory & Open cup & Mixed species & Insectivore \\
\hline Hyросnетоides maculicauda & 10 & 0 & Understory & Closed cup & Solitary/Family & Insectivore \\
\hline Isleria hauxwelli & 19 & 4 & Understory & Open cup & Mixed species & Insectivore \\
\hline Knipolegus poecilocercus & 6 & 0 & Ground & Closed cup & Solitary/family & Insectivore \\
\hline Lepidothrix nattereri & 23 & 0 & Sub canopy & Open cup & Solitary/family & Omnivore \\
\hline Leptotila rufaxilla & 5 & 0 & Understory & Open cup & Solitary/family & $\begin{array}{c}\text { Frugivore/ } \\
\text { Granivore }\end{array}$ \\
\hline Malacoptila rufa & 5 & 0 & Ground & Cavity & Mixed species & Insectivore \\
\hline Mionectes oleagineus & 6 & 1 & Understory & Closed cup & Mixed species & Omnivore \\
\hline Myrmoborus myotherinus & 22 & 9 & Understory & Open cup & Solitary/family & Insectivore \\
\hline Myrmornis torquata & 5 & 2 & Ground & Open cup & Solitary/family & Insectivore \\
\hline Myrmotherula axillaris & 19 & 6 & Understory & Open cup & Mixed species & Insectivore \\
\hline Myrmotherula longipennis & 17 & 5 & Sub canopy & Open cup & Mixed species & Insectivore \\
\hline Onychorhynchus coronatus & 8 & 0 & Sub canopy & Open cup & Solitary/family & Insectivore \\
\hline Philydor pyrrhodes & 5 & 0 & Sub canopy & Open cup & Solitary/family & Insectivore \\
\hline Phlegopsis nigromaculata & 28 & 11 & Ground & Open cup & Solitary/family & Insectivore \\
\hline Platyrinchus platyrhynchos & 6 & 0 & Sub canopy & Open cup & Solitary/family & Insectivore \\
\hline Ramphocelus carbo & 11 & 2 & Canopy & Open cup & Single species & Omnivore \\
\hline Rhegmatorhina berlepschi & 12 & 1 & Understory & Open cup & Solitary/family & Insectivore \\
\hline Rhytipterna simplex & 5 & 0 & Canopy & Open cup & Mixed species & Insectivore \\
\hline Saltator coerulescens & 5 & 0 & Canopy & Open cup & Mixed species & $\begin{array}{c}\text { Frugivore/ } \\
\text { Granivore }\end{array}$ \\
\hline Schiffornis turdina & 8 & 1 & Sub canopy & Cavity & Solitary/family & Insectivore \\
\hline Sporophila angolensis & 5 & 0 & Sub canopy & Open cup & Mixed species & Omnivore \\
\hline Thamnomanes saturninus & 25 & 10 & Sub canopy & Open cup & Mixed species & Insectivore \\
\hline Thamnophilus nigrocinereus & 11 & 7 & Sub canopy & Open cup & Solitary/family & Insectivore \\
\hline Turdus fumigatus & 7 & 2 & Canopy & Open cup & Solitary/family & Omnivore \\
\hline Willisornis poecilinotus & 14 & 7 & Understory & Cavity & Solitary/family & Insectivore \\
\hline Xenops minutus & 8 & 1 & Sub canopy & Cavity & Mixed species & Insectivore \\
\hline \multirow[t]{2}{*}{ Xiphorhynchus elegans } & 18 & 0 & Sub canopy & Cavity & Mixed species & Insectivore \\
\hline & 504 & 101 & & & & \\
\hline
\end{tabular}


Table A5. Mosquito species caught across five sites during the dry season. The geographic locations of sites can be found in Fig. 1

\begin{tabular}{|c|c|c|c|c|c|c|c|}
\hline \multirow[b]{2}{*}{ Subfamily } & \multirow[b]{2}{*}{ Tribe } & \multirow[b]{2}{*}{ Species/morph-species } & \multicolumn{5}{|c|}{ Sites } \\
\hline & & & TL1 & TL2 & TL4 & TR1 & JR1 \\
\hline Anophelinae & & Anopheles (Nyssorhynchus) nuneztovari s.l. & 3 & 0 & 3 & 0 & 0 \\
\hline Anophelinae & & Anopheles (Nyssorhynchus) oswaldoi s.l. & 0 & 26 & 0 & 0 & 0 \\
\hline Culicinae & Aedini & Psorophora (Fanthinosoma) amazonica cf. & 0 & 0 & 2 & 0 & 0 \\
\hline Culicinae & Culicini & Culex (Culex) chidesteri & 0 & 9 & 0 & 0 & 0 \\
\hline Culicinae & Culicini & Culex (Culex) sp. F-3 & 0 & 0 & 0 & 0 & 1 \\
\hline Culicinae & Culicini & Culex (Melanoconion) ocossa & 0 & 0 & 2 & 0 & 0 \\
\hline Culicinae & Culicini & Culex (Melanoconion) ribeirensis & 0 & 2 & 0 & 4 & 2 \\
\hline Culicinae & Culicini & Culex (Melanoconion) ribeirensis $\mathrm{F}-1$ & 0 & 0 & 0 & 4 & 0 \\
\hline Culicinae & Culicini & Culex (Melanoconion) sp. F-1 Group Intrincatus & 0 & 6 & 7 & 0 & 3 \\
\hline Culicinae & Culicini & $\begin{array}{l}\text { Culex (Melanoconion) sp. F-1 Section } \\
\text { Melanoconion }\end{array}$ & 0 & 0 & 0 & 2 & 0 \\
\hline Culicinae & Culicini & Culex (Melanoconion) sp. F-1 Subgroup Penai & 0 & 6 & 0 & 0 & 0 \\
\hline Culicinae & Culicini & Culex (Melanoconion) sp. F-2 Section Spissipes & 0 & 3 & 0 & 0 & 0 \\
\hline Culicinae & Culicini & Culex (Melanoconion) sp. F-2 Group Atratus & 0 & 5 & 0 & 0 & 0 \\
\hline Culicinae & Mansoniini & Coquillettidia (Rhynchotaenia) albicosta & 0 & 3 & 0 & 0 & 0 \\
\hline Culicinae & Mansoniini & Coquillettidia (Rhynchotaenia) hermanoi & 0 & 3 & 0 & 0 & 0 \\
\hline Culicinae & Mansoniini & Coquillettidia (Rhynchotaenia) juxtamansonia & 6 & 2 & 0 & 0 & 0 \\
\hline Culicinae & Mansoniini & Coquillettidia (Rhynchotaenia) lynchi & 0 & 6 & 2 & 0 & 0 \\
\hline Culicinae & Uranotaeniini & Uranotaenia (Uranotaenia) calosomata & 0 & 0 & 6 & 0 & 0 \\
\hline Anophelinae & & Anopheles (Nyssorhynchus) spp. & 0 & 5 & 0 & 0 & 0 \\
\hline Culicinae & Culicini & Culex (Melanoconion) spp. Section Melanoconion & 0 & 0 & 0 & 5 & 1 \\
\hline & & & 9 & 76 & 22 & 15 & 7 \\
\hline
\end{tabular}

Table A6. Mosquito species caught across four sites during the flooding season. The geographic locations of sites can be found in Fig. 1

\begin{tabular}{|c|c|c|c|c|c|c|}
\hline \multirow[b]{2}{*}{ Subfamily } & \multirow[b]{2}{*}{ Tribe } & \multirow[b]{2}{*}{ Species/morph-species } & \multicolumn{4}{|c|}{ Site } \\
\hline & & & TL1 & TL2 & TL3 & TI \\
\hline Anophelinae & & Anopheles (Nyssorhynchus) benarrochi & 1 & 0 & 0 & 0 \\
\hline Anophelinae & & Anopheles (Nyssorhynchus) nuneztovari s.l. & 3 & 2 & 1 & 0 \\
\hline Anophelinae & & Anopheles (Nyssorhynchus) oswaldoi s.l. & 2 & 18 & 19 & 0 \\
\hline Anophelinae & & Anopheles (Nyssorhynchus) rangeli & 0 & 0 & 1 & 0 \\
\hline Anophelinae & & Anopheles (Nyssorhynchus) triannulatus s.l. & 2 & 0 & 5 & 0 \\
\hline Anophelinae & & Chagasia bonneae & 0 & 5 & 0 & 0 \\
\hline Culicinae & Aedeomyiini & Aedeomyia (Aedeomyia) squamipennis & 0 & 0 & 0 & 2 \\
\hline Culicinae & Culicini & Culex (Anoedioporpa) quasioriginator & 1 & 0 & 0 & 0 \\
\hline Culicinae & Culicini & Culex (Culex) chidesteri & 1 & 1 & 1 & 0 \\
\hline Culicinae & Culicini & Culex (Culex) sp. F-1 & 1 & 1 & 0 & 0 \\
\hline Culicinae & Culicini & Culex (Culex) sp. F-2 & 0 & 1 & 2 & 0 \\
\hline Culicinae & Culicini & Culex (Culex) sp. F-3 & 0 & 0 & 1 & 0 \\
\hline Culicinae & Culicini & Culex (Culex) spp. Group coronator & 4 & 1 & 1 & 0 \\
\hline Culicinae & Culicini & Culex (Culex) surinamensis cf. & 1 & 0 & 0 & 0 \\
\hline Culicinae & Culicini & Culex (Melanoconion) inadmirabilis & 0 & 0 & 0 & 1 \\
\hline Culicinae & Culicini & Culex (Melanoconion) pedroi & 1 & 0 & 0 & 0 \\
\hline Culicinae & Culicini & Culex (Melanoconion) pilosus & 0 & 3 & 42 & 0 \\
\hline Culicinae & Culicini & Culex (Melanoconion) ribeirensis & 0 & 9 & 6 & 0 \\
\hline Culicinae & Culicini & Culex (Melanoconion) ribeirensis $\mathrm{F}-1$ & 1 & 1 & 0 & 0 \\
\hline Culicinae & Culicini & Culex (Melanoconion) saramaccensis $c f$. & 0 & 0 & 3 & 0 \\
\hline Culicinae & Culicini & Culex (Melanoconion) sp. F-1 Group Intrincatus & 2 & 10 & 55 & 0 \\
\hline Culicinae & Culicini & Culex (Melanoconion) sp. F-1 Section Spissipes & 0 & 0 & 5 & 0 \\
\hline Culicinae & Culicini & Culex (Melanoconion) sp. F-1 Section Melanoconion & 0 & 0 & 2 & 0 \\
\hline Culicinae & Culicini & Culex (Melanoconion) sp. F-1 Subgroup Penai & 0 & 4 & 2 & 0 \\
\hline Culicinae & Culicini & Culex (Melanoconion) sp. F-1 Group Atratus & 0 & 1 & 0 & 0 \\
\hline Culicinae & Culicini & Culex (Melanoconion) sp. F-2 Group Atratus & 2 & 0 & 6 & 0 \\
\hline Culicinae & Culicini & Culex (Melanoconion) sp. F-3 Section Spissipes & 0 & 4 & 15 & 0 \\
\hline Culicinae & Culicini & Culex (Melanoconion) sp. F-2 Section Melanoconion & 1 & 0 & 0 & 0 \\
\hline
\end{tabular}


Table A6. (Cont.)

\begin{tabular}{|c|c|c|c|c|c|c|}
\hline \multirow[b]{2}{*}{ Subfamily } & \multirow[b]{2}{*}{ Tribe } & \multirow[b]{2}{*}{ Species/morph-species } & \multicolumn{4}{|c|}{ Site } \\
\hline & & & TL1 & TL2 & TL3 & $\mathrm{TI}$ \\
\hline Culicinae & Culicini & Culex (Melanoconion) sp. F-3 Section Melanoconion & 0 & 0 & 1 & 0 \\
\hline Culicinae & Culicini & Culex (Melanoconion) sp. F-4 Section Melanoconion & 1 & 0 & 0 & 0 \\
\hline Culicinae & Culicini & Culex (Melanoconion) sp. F-5 Section Melanoconion & 0 & 0 & 1 & 0 \\
\hline Culicinae & Culicini & Culex (Melanoconion) spissipes & 0 & 1 & 1 & 0 \\
\hline Culicinae & Culicini & Culex (Melanoconion) theobaldi & 0 & 2 & 3 & 0 \\
\hline Culicinae & Mansoniini & Coquillettidia (Rhynchotaenia) albicosta & 5 & 1 & 0 & 0 \\
\hline Culicinae & Mansoniini & Coquillettidia (Rhynchotaenia) hermanoi & 5 & 2 & 0 & 0 \\
\hline Culicinae & Mansoniini & Coquillettidia (Rhynchotaenia) juxtamansonia & 25 & 2 & 0 & 0 \\
\hline Culicinae & Mansoniini & Coquillettidia (Rhynchotaenia) lynchi & 1 & 4 & 0 & 0 \\
\hline Culicinae & Mansoniini & Coquillettidia (Rhynchotaenia) venezuelensis & 0 & 0 & 4 & 0 \\
\hline Culicinae & Mansoniini & Mansonia (Mansonia) titillans & 10 & 0 & 0 & 2 \\
\hline Culicinae & Sabethini & Sabethes (Sabethes) sp. F-1 & 0 & 1 & 0 & 0 \\
\hline Culicinae & Uranotaeniini & Uranotaenia (Uranotaenia) apicalis & 1 & 0 & 2 & 0 \\
\hline Culicinae & Uranotaeniini & Uranotaenia (Uranotaenia) calosomata & 1 & 0 & 1 & 0 \\
\hline Culicinae & Uranotaeniini & Uranotaenia (Uranotaenia) geometrica & 0 & 0 & 6 & 0 \\
\hline Culicinae & Uranotaeniini & Uranotaenia (Uranotaenia) geometrica $\mathrm{F}-1$ & 1 & 0 & 19 & 0 \\
\hline Culicinae & Uranotaeniini & Uranotaenia (Uranotaenia) sp. F-1 & 0 & 2 & 0 & 0 \\
\hline Culicinae & Uranotaeniini & Uranotaenia (Uranotaenia) sp. F-2 & 1 & 1 & 1 & 0 \\
\hline Culicinae & Uranotaeniini & Uranotaenia (Uranotaenia) sp. F-3 & 0 & 0 & 1 & 0 \\
\hline Culicinae & Incerta & Culicidae morphotype 1 & 2 & 0 & 0 & 0 \\
\hline Anophelinae & & Anopheles (Nyssorhynchus) sp. & 0 & 1 & 0 & 0 \\
\hline Culicinae & Aedini & Aedes (Ochlerotatus) sp. & 1 & 0 & 0 & 0 \\
\hline Culicinae & Culicini & Culex (Melanoconion) spp. Section Melanoconion & 0 & 5 & 6 & 3 \\
\hline Culicinae & Mansoniini & Coquillettidia (Rhynchotaenia) sp. & 0 & 1 & 0 & 0 \\
\hline & & & 77 & 84 & 213 & 8 \\
\hline
\end{tabular}

